\title{
Medya sektöründe Sanayi 4.0 uygulaması: TRT örneği
}

\section{Industry 4.0 implementation in the media sector: TRT example}

\author{
Beyza Toksoy ${ }^{1}$ \\ Birol Uzunay ${ }^{2}$ \\ 1 Dr. Öğrt. Üyesi, Okan Üniversitesi, Meslek Yüksekokulu, İnsan Kaynakları Yönetimi Programı, Türkiye, e-mail: beyza.toksoy@okan.edu.tr \\ 2 Dr., Kamu çalışanı, Türkiye, e-mail: biroluzunay@hotmail.com
}

\section{Öz}

Medya sektöründe, yayın üretim teknikleri hızla değişmektedir. Bu değişiklikler, önce küreselleşme ve dijitalleşmenin etkisiyle oluşmuştur. Daha sonra sanayi 4.0 üretim tekniklerinin alt yapısı medyada uygulanmaya başlamıştır.

Sanayi 4.0 sürecini öngörerek alt yapılarını hazırlayan medya şirketlerinin, yüksek düzeyde rekabet gücü kazanabilecekleri yorumlanmaktadır. Türkiye'deki özel sektör medya şirketlerinin ve kamu yayın kurumlarının; Sanayi 4.0'a yatırım yaparak, yayın üretimlerini buna göre ayarlamalarının bir tercih değil zorunluluk olduğu öngörülmektedir.

Bu makalenin saha araştırılmasında Türkiye Radyo Televizyon Kurumu'nun (TRT) seçilmesinin nedeni, bir kamu kurumu olarak son 12 yılda dijital teknolojiye yaptığı yatırımlardır. Ayrıca TRT'nin küreselleşme uyumu için yapılan idari, mali ve teknik yatırımları önemli bulunmaktadır. TRT, yayın politikalarıyla kamuoyunda çok eleştirilse de küreselleşme uyum çalışmaları ve dijitalleşme yatırımlarıyla özel sektör yayın işletmelerinin ve diğer kamu kurumlarının önüne geçtiği öngörülmektedir.

Çalışma bir yayın kurumunda, Sanayi 4.0 teknolojilerinin nasıl uygulanabileceğini gösteren düzenlemelere örnek teşkil etmesi amacıyla yapılmıştır. Bu amaçla TRT kurumunun Sanayi 4.0 alt yapı yatırımları; literatür, saha araştırması ve yapılan röportajlarla incelenmiştir. Röportaj yapılan TRT uzmanları A1, A2 ve A3 olarak belirtilmiştir.

Anahtar kelimeler: Sanayi 4.0, Dijitalleşme, TRT

JEL kodları: D2, D20, D23, D24

\begin{abstract}
Production techniques of the media industry are changing rapidly. This change first occurred with the effect of globalization and digitalization. Later, industry 4.0 production techniques were developed.

It is thought that media companies that prepare their infrastructures by foreseeing the industry 4.0 process will be able to gain a high level of competitive power. Private sector media companies and public broadcasting institutions in Turkey; it is interpreted that investing in industry 4.0 and adjusting their broadcast production accordingly is no longer a choice but an obligation.
\end{abstract}

Citation/Atıf: TOKSOY, B. \& UZUNAY, B., (2021). Medya sektöründe Sanayi 4.0 uygulamasi: TRT örneği. Journal of Life Economics. 8(4): 431-441, DOI: 10.15637/ jlecon.8.4.03

Corresponding Author/ Sorumlu Yazar:

Beyza Toksoy

E-mail: beyza.toksoy@okan.edu.tr
Bu derginin içerĭ̆̈i Creative Commons Attribution-NonCommercial 4.0 Uluslararası Lisansı altında lisanslanmıı̧tır.

Content of this journal is licensed under a Creative Commons Attribution-NonCommercial 4.0 International License. 
The reason for choosing the Turkish Radio and Television Corporation (TRT) in the field research of this article is the investments it has made in digital technology in the last 12 years as a public institution. In addition, the administrative, financial and technical investments made for globalization alignment are very important. Although TRT institution has been criticized by the public for its broadcasting policies, it is thought that it has surpassed private sector broadcasting enterprises and other public institutions with its globalization adaptation studies and digitalization investments.

The study was conducted to set an example for the policies and regulations that show how industry 4.0 technologies can be applied in a broadcasting institution. for this purpose, TRT's industry 4.0 investments; the literature has been examined through field research and interviews. Interviewed TRT experts are specified as A1, A2 and A3.

Keywords: Industry 4.0, Digitalization, TRT

JEL codes: D2, D20, D23, D24

\section{GíRİş}

Su ve buhar enerjisinin, makina sistemlerini seri olarak çalıştırmasıyla başlayan sanayi devriminin ilk evresi, sadece teknolojiyi değil; yaşam biçiminin de değişimini başlatmıştır. 19. yüzyılın ilk dönemlerinde, elektrik enerjisi ile kitlesel üretimin başlamasıyla, sanayi devriminin ikinci dönemi başlamıştır. Üçüncü dönem ise 1970'li yıllardan sonra bilgi teknolojilerinin iş ve sosyal yaşama girmesi ile gelişmiştir (Koca, 2018:245-252)

Birinci sanayi devrimi ortalama 1760'dan 1840'lara kadar devam etmiştir. Birinci sanayi devriminde, demiryollarının yapımı ve buhar makinesinin çalıştırılarak mekanik, seri üretim başarılmıştır. 20. yüzyılın ilk döneminde ortaya çıkan ikinci sanayi devrimi, elektriğin ve montaj hattının geliştirilmesiyle; seri üretim farklı sektörlerde de yaygınlaşmıştır. Üçüncü sanayi devrimi ise 1960'lı yıllarda ilk etkilerini göstermiștir. Bireysel bilgisayarların (1980'ler) ve internetin (1990'lar) öncülügüünde oluştuğu için bu dönem; "bilgisayar devrimi" ya da "dijital devrim" olarak isimlendirilmiştir (Güvenç vd., 2017:1-9).

21. yüzyılda ise siber ve fiziksel üretim tesislerinin aynı ortamda aynı amaç için kullanılması ile sanayi devriminin dördüncü evresi olan @Sanayi 4.0" dönemi başlamıştır. Endüstri 4.0 olarak da tanımlanabilen "dördüncü sanayi devrimi" (sanayi 4.0), 2011 yılında ilk kez Almanya'da kavramsallaştırılmıştır. Dördüncü Sanayi Devrimi, yakın döneme kadar üretilmiş üretim cihazlarının siber yazılımlar ile buluştuğu entegre bir sistemi anlatmaktadır.

Dördüncü Sanayi Devrimi'nde, nesne olarak analiz edilen ve internet yoluyla iletişim kurabilen makinalar arasında; akıllı okuyucular (sensörler), robotlar, insansız üretim araçları vb. tüm cihazlar bulunmaktadir.

Bu üretim sistemleri, fiziksel dünya ile siber dünyayı birleştirerek yeni üretim ve iletişim teknikleri geliştirmiştir. Siber ve fiziksel sistemleri birleştiren dijital sistemler; öngörü analizleri ve geçmiş verilerin raporlanmasıyla geleceğe ait verileri hazırlayabilmektedir (Özdoğan, 2017:37).

İleri üretim sistemlerinde, "dijital teknoloji" sadece yeni üretim sistemlerini kullanmak değil; yeni yöntemle ile sorunları çözmek ve iş performansını büyütmeyi amaçlanmaktadır. Üretim cihazlarının çeşitleri, akıllı sensörler, yazılım robotları, gelişmiş ara yüzler, yapay zekânın türevleri, 3D yazıcılar gibi yeni sistemlerden oluşacağı yorumlanmaktadır. Son sanayi devrimi olarak Sanayi 4.0, insanın, üretim sürecindeki etkinliği kısıtlanarak; kas gücünü değil, yazılım gücünü öne alan bir üretim sisteminden oluşmaktadır. Merkezi olmayan bir üretim özelliği olan Sanayi 4.0, siber fiziksel üretim sistemleriyle; üretim aşamasında, insanlar, makineler ve ürünler arasında verimli bir iletişim kurmayı amaçlamaktadır (Koca, 2018: 245-252).

Yeni üretim ağlarında; siber ve fiziksel üretim mekanizmaları, dinamik bir yapıdadır ve her dönem gelişir. Sanayi 4.0, üretim sisteminde; "nesnelerin interneti, yapay gerçeklik, bulut teknolojisi, büyük veri, dijital ekonomi" gibi kavramlar incelenmektedir. Siber fiziksel üretim mekanizmaları, bilgi ve materyal alt sistemlerindeki araçları kapsamaktadır (Ivanov vd., 2016: 386).

Sanayi 4.0, akıllı teknoloji ve tekniklerin üretimin her basamağında kullanılarak; merkezileşmiş üretim özelliğinin azaltıldığı; esnek üretimin arttı̆̆ bir üretim sistemidir (Kasa, Arslan, 2020:1810-1826). Mekanizasyon, elektrik ve IT sayesinde yeni üretim şekilleri gelişim sağlamıştır. Sanayi 4.0 ise, akıllı ve merkezi olmayan bir üretim özelliğini taşımaktadır. Dördüncü Sanayi Devrimi ile siber fiziksel üretim mekanizmalarının tüm üretim döneminde insanlar, makineler ve ürünler arasında kesintisiz bir iletişimi oluşmaktadır. Maliyet ve zaman kazancını sağlayıp; ürün kalitesini artırmak, Sanayi 4.0'ın temel yararları arasında gösterilmektedir (Albers vd., 2016: 262).

Müşteri taleplerini gerçekleştirebilmek için akıllı ve dinamik bir imalat ekosistemi oluşturmayı amaçla- 
yan sanayi 4.07da, akıllı makinalar; üretim sürecinin ne durumda olduğunu anlayarak bir sorun oluşursa, bunu en az insan müdahalesiyle gerektirecek biçimde çalışmaktadır (Suri vd, 2017: 2).

Dördüncü Sanayi Devrimi üretim tarzında; sanayi devrimlerinin ilk üç döneminden farklı olarak, tüm teknolojik üretim sistemlerinin kendi zekâlarına sahip olmalarıyla; ürettikleri veriden kendilerine anlam ç1karabilmektedirler (Almada, 2015: 16). Bilgi ve internet teknolojilerinin üretime yansıtılmasıyla üretimde esneklik, kaynak ve maliyet tasarrufu, yeni iş akış modelleri oluşturan Sanayi 4.0; otomasyon, üretim gözetimi, planlama ve bilgi teknolojileri Sanayi 4.0 yeni iş modelinde, temel faktörler olmuştur (Abersfelder vd., 2016: 467).

Yeni sanayi devriminde; bilişim, internet sistemlerinin; üretim mekanizmalarına entegrasyonu ve süreçler arası ağların uyumuyla çalışır. Sistemin etkinliği, dijital sisteme ve akıllı cihazlara bağlanan teknoloji ve süreçlerle problemsiz biçimde işlenen bir ekonomiye bağlıdır. Çünkü sanayi 4.0'ın dayandığı temel güç, akıllı hizmetler sağlayan siber yazılımların, fiziksel üretim araçlarını yönetmesidir (IEC, 2015:24).

Küreselleşmeyle; finansal erişimin hızlı, güvenilir olması, ulaşım maliyetlerinin düşmesi, sermayenin işgücü maliyetleri düşük olan Çin gibi ülkelere geçmesini sağlamıştır. Almanya, Amerika, Japonya ve İngiltere hükümetlerince teşvik edilen Sanayi 4.0'1n geliştirilme nedenleri arasında Çin'in üretim ağını yaygınlaştırarak küresel piyasaları ele geçirme tehlikesi de gösterilmektedir (Emara ve Kasa, 2020:56).

Makalenin araştırma sorusu “Türkiye'de medya işletmelerinde Sanayi 4.0 çalışmaları hangi ölçüde yapılabilmektedir?" Bu araştırma sorusu, "TRT kurumundaki Sanayi 4.0 çalışmaları" özelinde incelenmiştir.

Bu çalışma ile Türkiye kamu kurumları için yeni bir kavram olan Sanayi 4.0'ın TRT örneği incelenerek; diğer kamu kurumlarındaki çalışmaların ortaya çıkartılabilmesi amaçlanmaktadır.

\section{2. ŞİRKETLERIN VE KAMU KURUMLA- RININ SANAYI 4.0 UYUMU}

Sanayi 4.0'ın yeni üretim tarzını uygulayabilen işletmeler/kurumlar; çalışanlarla uyumlu çalışan akıllı yazılım sistemleri sayesinde, gelişen pazar ve müşteri isteklerine çabuk ve verimli bir biçimde uyum gösterebilmektedir (EFFRA, 2013:61).

Yeni dönemde, ticaret savaşlarının içinde yapay zekâ yazılım sistemleri, hızlı biçimde yayılmaktadır. Yapay zekâ sadece üretim kalitesini artırmıyor aynı zamanda tüketiciyi bir veri kaynağı olarak kullanıyor. Bu yüzden de, Sanayi 4.0 yatırım süreçlerine uyum sağlayamayan, yeni sanayi devriminin stratejisini belirle- meyen işletmeler ve kamu kurumları, rekabet edemeyerek ayakta kalmakta zorlanacaklardır (TOBB, 2016). Çünkü yeni sanayi devrimiyle üretim, kalite ve müşteri tercihleri farklı boyutta analiz ediliyor. Tüketici bireylerin ilgi ve yönelişlerine etki eden algoritmalar ve bireysel bilgileri depolayıp analiz edebilen yazılımlar; tüketicilerin, mali yapılarını, sosyal-kültürel özelliklerini, etkileşimlerini ve siyasi eğilimlerini çözümleyip müşteri odaklı üretim/hizmet gerçekleştirebilmektedir.

Sanayi 4.0 vizyonu, merkeze tüketiciyi alan üretiminin yanında; tam zamanlı kontrol, entegre üretim, tedarik zinciri boyunca artan işbirliği ve yazılımlarla akıllı sistemler oluşturan yeni iş modellerini içermektedir (Branke vd., 2016: 264).

21.yüzyılı ilk döneminden itibaren toplumların dönüşümü teknolojik gelişmenin hızıyla doğru orantılı olarak değişmektedir. Örneğin, avc1-toplayıcı yaşam biçiminden, tarım toplumuna gelebilmek için 200 bin yıllık bir zaman harcandığı analiz edilmektedir. Sanayi toplumunun mekanik üretim sisteminden, bilgi toplumuna yükselme zamanı ise 300 yıl olarak yorumlanıyor. Günümüzde ise sadece 20 yıllık bir zaman dilimi içinde; büyük sanayi ve kültür devrimleri yaşanıp; toplumsal yaşam değişebilmektedir. Birinci sanayi devrimini sembolize eden iplik makinelerinin Avrupa ülkelerinden dünyaya yayılması yaklaşık 120 yıl olurken; internetin tüm dünyada kullanılabilmesi ise sadece 10 yılda tamamlanmıştır (Schwab, 2016: 17).

Bu nedenle de, dördüncü sanayi devrimi tanımlamasından sonra 10 yıl geçtikten sonra teknolojik ilerlemelerle birlikte toplumlar, yeni bir kırılma dönemiyle karşılaşabileceklerdir (Koçak, 2020:1-5). Bu sebeple de rekabet gücünü büyütme amacı taşıyan işletmelerin, üretim, dağıtım ve satış organizasyonlarına Sanayi 4.0 uygulamaları getirip; akıllı robot yazılımları, siber-fiziksel mekanizmalar, bulut tabanlı üretim gibi yeniliklere yatırım yapmaları gerekmektedir (Kasa, Arslan, 2020:1810-1826).

Dördüncü sanayi devriminin şirketleri doğrudan etkileyebilecek değişimleri şöyle özetleniyor.

- Üretimde, hiz, kalite kontrolü, mikro-reaktörler ile esneklik, tasarruf ve verimlilik büyüyecektir.

- Sanayi 4.0'ın, birçok mesleğin “değişimine" neden olacağı ve yeni mesleklerin doğması öngörülmektedir.

- Kişiselleştirilmiş üretim yaygınlaşacaktır.

- Yeni ve inovatif ürünlerin müşteri ile buluşma süresi kisalacaktır.

- İnsansız üretim ile işçilik ve enerji tasarrufu sağlanabilecek.

- Bireylerin yüzde 80'ni dijital bir varlığa sahip olacaktır. 
- Bireylerin yüzde $10^{\prime}$ unun internete bağlanabilen giysiler giymesi öngörülüyor.

- 1 trilyon sensörün internete bağlanması imkânlı hale gelebilecektir.

- Tüketici ürünlerinin yüzde 5'inin 3D basılması ve 3D yazıcılar ile ilk otomobil üretimi olabilecektir.

- Şirket işleyiş denetimlerinin yüzde 30'unun yapay zekâ tarafından yapılabilecektir (TOBB, 2016:16-25).

Sanayi 4.0 devriminin oluşturacağ 1 fırsatlardan yararlanmak ve ağır rekabet koşularından korunmak için firmaların özel olarak AR-GE çalışmaları yapmaları ve bu konu için önemli miktarda yatırım bütçeleri ayırmaları gerekmektedir (Bağc1, 2018:122-125).

Yeni üretim tarzının otomasyon süreçlerine adaptasyon sağlanması için gerekli yazılım programlarının geliştirilmesi ve veri işleme ve veri madenciliği teknolojilerinin kullanılması gereklidir. Çünkü modern üretim işletmeleri için M2M bulut bağlantısıyla dinamik üretim mekanizmalarının geliştirilmesi, üretim araç ve cihazlarının birbiriyle uyumlu olması sağlanabilecektir (EFFRA, 2013:60-69).

Sanayi 4.0 ile üretim ve çalışma tarzını değiştirecek olan işletmelerin ve kurumların; ticari ve teknik yeteneği birleştirebilecek, matematik, mühendislik ve teknolojik bilgi birimine sahip, yüksek nitelikli personel ve yöneticileri yetiştirmeleri gerektiği, analiz edilmektedir.

Yine ticaret savaşlarında; üretimde sürekliliğin ve bir artışın olması gerekmektedir. Türk şirketlerinin, küresel rekabette var olabilmesi için inovasyon çalışmalarl, modern yazılım ve programların üretim sistemine uyumlu hale getirilmesi gerekmektedir. Türk işletmelerinin yeni üretim tekniklerinde dışarıdan danışmanlık alma konusuna uzak kalındığı tespit edilmektedir (Ünal, 2018: 265-267).

Sanayi 4,0 kavramı, gelişmiş ülkelerde (ABD, Almanya, Japonya, Finlandiya ve İngiltere) teorik kavram tartışmalarından ziyade; farklı sektörlerde ki, uygulama pratikleriyle dikkati çekmektedir. Bu ülkelerde Sanayi 4.0 uygulamaları devlet teşvikiyle; özel stratejilerle destekleniyor. Batı Avrupa'da sanayi 4.0 uyumu için dijital işletme yatırımı yapan küçük yatırımcıların payı yüzde 87 iken, büyük yatırımcıların oranı yüzde 61'dir. Almanya, Federal Eğitim ve Araştırma Bakanlığg'nın Sanayi 4.0 ar-ge'si için 200 milyon Euro bütçe kullanmıştır. Almanya ayrıca Sanayi 4.0 için her yıl için 20 milyar Euro altyapı yatırımı yapmıştır. İngiltere ve Finlandiya, Sanayi 4.0 değerli üretiminin yaygınlaşması için teşvik bütçesi ayırmıştır (Türk vd., 2014:2-7).

Önümüzdeki 5-10 yılda, robot yazılımların, gelenek- sel endüstrilerin çoğunluğunu etkisiz hale getireceği öngörülüyor. Bugün dünyanın en büyük şirketlerinden Uber'in kendi mülkiyetinde taksisi yok, küresel konaklama sağlayıcısı Airbnb'nin oteli yok. En büyük sosyal medya şirketi Facebook içerik üretmiyor; küresel e-ticaret sitesi Alibaba.com'un ise deposu bulunmamaktadır. Bu bağlamda, Türkiye'deki özel sektör işletmelerinin ve kamu kurumlarının; sanayi 4,0 yönünde yatırım yapıp üretimlerini buna göre ayarlamalarının bir tercih değil; bir zorunluluk olduğu yorumlanmaktadir.

Türkiye'de sanayi 4,0 uyumu başarılabildiğinde; üretimde rekabet gücü büyümesi, sürdürülebilirlik elde edilecektir. Katma değer yönü daha yüksek olan ürün ve hizmetler üretilecektir. Türkiye'deki üretim sektöründe ilk etapta yüzde 4 ila yüzde 7 verimlilik artışı sağlanabilir. Yine sanayi üretiminde fazladan yüzde 3 büyüme gerçekleştirilebilir. Sanayi 4.0 uyumu için gelecek 10 yılda üretici gelirlerinin yüzde 1-1,5'ini karşılayan 10-15 milyar TL seviyesinde yatırım gerektiği yorumlanmaktadır (Şuman, 2017:92).

Türkiye'de dijitalleşmesinin yaygınlaşması, küresel üretim tekniklerinin satın alınabilmesiyle; Sanayi 4.0 yatırımları yapılabilmektedir. Türkiye'de de belirli işletmeler Sanayi 4,0 üretim tarzına yatırım yaptıklarını açıklamışlardır. İlk etapta, Burdur Sanayi Odası'nda Sanayi 4.0 eğitimlerinin verilmesi, Ford Otosan'da 1500 ar-ge çalışanıyla ilk otonom kamyonun üretilmesi, Kocaeli Belediyesi'nde Sanayi 4.0 laboratuvarının kurulması, Arçelik'te robot üretilmesi, Sanayi 4.0 konusunda yapılan ilk çalışmalar olarak bilinmektedir (Yüzak, 2016).

Türkiye'de Sanayi 4,0 kavramsal olarak yatırım yapan şirket ve kamu kurum sayısının az olduğu gözlemlenmektedir. Kibar Holding, Türkiye Siemens, Bosh Türkiye ve Vestel gibi önemli şirketler, Sanayi 4,0 yatırımlarını yaptıklarını açıladılar (Özata, 2016). Üniversiteler ve TÜBİTAK Sanayi 4,0 üzerinde çalışmalar yapmaktadır. TÜBİTAK'ın hazırladığ 1 “Yeni Sanayi Devrimi Akıllı Üretim Sistemleri Teknoloji Yol Haritası" isimli rapor, teknoloji gruplarına göre Sanayi 4.0 için olabilecek ar-ge projelerini özetlemiştir (TÜBITAK, 2016:1).

Sanayi 4.0 kavramının Türkiye'de tartışılmaya başlanmasıyla; bu sanayi devrimi dönüşümü için hangi sektörlerin öncelikli olacağı, işletmelerin geçiș sürecinde nasıl bir altyapıya sahip olması gerektiği yeni yatırımlar için hangi miktarda finansal kaynak ayrılmas1 gerektiği araştırma aşamasındadır (Kasa, Arslan, 2020:1810-1826)

Dördüncü sanayi devrimi sadece akıllı makine ve yazılımlarla ilgili olmayıp sektör çeşitliliği çok büyüktür. Gen diziliminden, yenilenebilir enerjilere, kuantumdan bilgi işleme ve nano teknolojilere farklı 
sektörlerde eş zamanlı ileri atılım dalgaları yayılmaktadır (Öztürk ve Alaşahan, 2019:3). Sanayi 4.0 teknolojileri, tanımlamasını yapamasak bile günümüzde farklı sektörler de kullanılıyor. Sanayi 4.0 endüstriyel üretim ve yönetim faaliyetleri, pandemi döneminde sağlık alanında, e-ticaret işlemlerinde, modern imalat sistemlerinde, uzaktan öğretim uygulamalarında uygulanmıştır (Yiğitol ve Sarı, 2020:67).

Türkiye'de sanayi ürünü ve hizmet sektöründe kamu gücü göz önüne alınırsa; kamu kurumlarının da Sanayi 4.0 yatırımlarını yapması gerektiği yorumlanmaktadir.

Türkiye'de henüz resmi olarak bir kamu kurumu Sanayi 4.0 için strateji geliştirip üretime geçtiğini açıklanmamıştır. Ancak bazı kamu kurumlarında "küreselleşme uyum çalışmaları" ve "dijitalleşme yatırımlarıyla" sanayi $4.0^{\prime}$ ın alt yapısı oluşturulmaktadir.

\subsection{Sanayi 4.0'ın Medya İşletmelerinde Uygulanma- s1 ve TRT Örneği}

Dördüncü sanayi devrimi, sanayi sektöründe ön plana çıkmakla birlikte teknolojik gelişmelere öncülük etmiş ve farklı sektörlerde uygulanabilmektedir. Sanayi 4.0 üretim teknikleri genel anlamda somut ürün üretimindeki dijital sistemin bütünleşmiş yapısını anlatıyor. Ancak Sanayi 4.0 üretici ve hedef kitle arasında iletişim, zaman, üretim verimini sağlayıp yenilikler oluşturulabilen ve sonuçları her işletme için ayrı ayrı analiz edilmesi gereken özellikler taşımaktadır.

Sanayi $4.0^{\prime} \mathrm{n}$, iş yaşamının pek sektöründe yenilikleri başlatacağı kabullenilmiş bir gerçek iken, bu üretim devriminin medya sektöründe yansıması olağan bir sonuçtur. Medya sektörün teknolojinin ağırlıkta olduğu bir gelişim göstermesi öngörülmektedir (Akgül ve Ayer, 2018:2311). Çünkü dijital medya mecralarının yaygınlaşmasıyla "zamansız ve mekansız" yayıncılık başlamıştır. Ayrıca yeni medya düzeninde salt yazılı ya da salt görsel yayıncılık yapılmamaktadır. Melez yayıncılık anlayışıyla, "televizyon, video, gazete hatta haber ajans yayıncılığı" internet ortamında tek bir yayın markası altında toplanmaktadır.

Sanayi 4.0, sadece bir sektörün değil, bir üretim hatt1nın değil; bir işletmenin bütün çalışma ve süreçlerinin dijitalleşmesi olarak da kavramsallaştırılabilir (Kıvılcım, 2013: 226). Bu yüzden de bir televizyon kuruluşunun Sanayi 4.0 yatırımları yapması, dijital yayıncılığın yaygınlaştı̆̆ı medya sektöründe olağan bir sonuç olarak yorumlanmaktadır.

Televizyon yayıncılığında sanayi 4.0 argümanlarının kullanılması ise gelişen teknolojiyle iletişimin ucuzlaması, dijital yayıncılığın geleneksel yayıncılığın önüne geçmesi, yayın rekabetinin küreselleşmesi, yayıncılıkta insan faktörünün azalmasıyla açıklanabilmektedir.
$\mathrm{Bu}$ makalenin saha araştırılmasında, Türkiye Radyo Televizyon Kurumu'nun seçilmesinin nedeni, bir kamu kurumu olarak son 12 yılda dijital teknolojiye yaptığı yatırımların fazla olması ve küreselleşme uyumu için yapılan idari, mali ve teknik yatırımların önemli bulunmasıdır.

TRT Genel Müdürlüğü, 16 televizyonu, 17 radyo kanalı, 4 dergi ve dijital yayın markalarıla 41 dilde yayın yapan özerk yönetimli 3.399.315.000 TL bütçesi olan bir kamu yayın kurumu konumundadır (Eren 2020:1). Türkiye Radyo Televizyon Kurumu'nun son 12 yılda yaklaşık olarak 1,5 milyar TL'lik teknik yayın yatırım yaptığı analiz edilmektedir (TRT Bilançoları 2008-2019).

TRT Genel Müdürlüğü, yayın teknolojine dair tüm mekanik cihazları yenilerken; dijital yayıncılık için de önemli yatırımlar yapmıştır. Yine TRT'nin iddialı bulunan TRT World televizyon kanalı sadece Türkiye'de değil, dünyanın en önemli teknik ve yayın yatırımlarını alan televizyonlarından markalarından biri olarak yorumlanmaktadır.

Küreselleşme ve son yıllarda ivmesini artıran Dördüncü sanayi devriminin medya sektöründe sahiplik yapısını önemli ölçüde değiştirmiştir (Bayram, 2013:1). Dijital medyanın sosyal medya aracılığıyla yayılmasından sonra medya işletmesi sahibi olmak için ilk vasfın sermaye sahibi olma şartı zayıflamıştır. Dijital medya döneminde yetenek, hayal gücü, zekâ ve farklılık önem kazanmıştır. Bu yüzden de bir muhabir ya da bir yazarın kurduğu internet siteleri, youtube kanalları, Türkiye'nin en çok takip edilen medya yayın organlarından olmuştur. Farklı yorum yapabilen, dijitalleşme tekniklerini takip edebilen girişimciler; köklü televizyonlardan ve gazetelerden daha çok kişiye ulaşabilmektedir.

Oxford Üniversitesi, Reuters Enstitüsü'nün “Dijital Haber Raporu 2016" isimli anket çalışmasına göre; 26 ülkede soru sorulan deneklerin yüzde 51'i sosyal medya araçlarını birincil haber merkezi olarak tanımlamaktadır. 19 ile 24 yaş oranındaki bireylerin yüzde 28 'i ana haber kaynağı olarak sosyal medyayı tercih ediyor (Akgül ve Ayer, 2018:2320).

Dünyada ve Türkiye'de televizyon izleme süresi hızla düşmektedir. 4 yıl önce günlük 5 saat olan kişi başı televizyon izleme süresi 2020'de 3 saat 20 dakikaya inmiş durumdadır. 20 yaş altı televizyon izleme süresi ise günlük 1 saatin altına inmiş durumdadır (Eren, 2019, 2020).

Bu bağlamda, TRT kurumunun, geleneksel televizyon ve radyo yayıncılığının dışında dijital medyaya yatırım yapması; sanayi 4.0 anlayışıyla çalışma sistemi kurması; gelecekte izleyici/dinleyici bulabilmesi adına bir zorunluluk olarak yorumlanabilmektedir. 
TRT, televizyon ve radyo yayıncılı̆̆ 1 yapan bir kamu işletmesi konumunda bulunuyor. Sanayi 4.0'in TRT'nin ana üretim alanı olan "yayın üretimine" olan uyumunun ise dünyada örnekleri oluşmaya başlamıştır. 2016 yılında Japonya'da, geliştirilen yapay zekânın yazdığı roman; edebiyat yarışmasında ikincilik ödülü kazand. Yine Şehrazat ismindeki yapay zekâ, analiz ettiği hikâyelerde tekrarlanan motifleri kullanarak bir televizyon senaryosu üretmiştir (Koçak, 2020:11). Yapay zekânın roman, senaryo yazabilmesi; televizyon yayıncılığ 1 sektöründe, en zor üretimi olan film senaryosu yazımında dahi başarılı olabileceğini yorumlatabiliyor.

Televizyon yayın sektöründe, Sanayi 4.0 yenilikleriyle; 1şık, kamera, montaj, sunum ve program metinlerin yazıcı robotlar tarafından üretildiği bir çalışma ortama doğmaktadır. Bir yayın metninin, oluşturulmasında, metni üreten insan ve robot birlikteliğiyle melez çalışma ortamı yaygınlaşabilecektir. Sanayi 4.0'ın televizyon dünyasına uyarlanmasıyla melez çalışma iklimiyle yazıcı robotlara, bir kültüre ait anlatı metinlerinin yükleniyor ve insan beyninden farklı üretim yapan bir kurmaca haber/program metni ya da film senaryosu elde edilebiliyor (Koçak, 2020:11).

İnsan beyni ve hayal gücüne katkı olarak; sözlü, yazılı ve dijital varyantların, yapay zekâ gücüyle birleşmesiyle; anlatı geleneğinde yaratıcılığının sorgulanacağ 1 bir üretim şekli oluşmaktadır (Bağcl, 2018:123-125).

Mareika Jenner ve Roberta Pearson televizyonun dört ana gelişim süreci olduğunu ve bu yaşadığımız bu dönemin "Televizyon 4.0" olarak tanımlanabileceğini literatüre kazandırmışlardır. Televizyonun birinci dönemi (1950-1980) arasında, eğitici ve günlük olarak, "zaman geçirici" niteliklerinin olup olmadığının sorgulandığ1 bir dönemdir. İkinci dönemde (1980-1995) reklama ve popüler kültüre yönelik yayınlar öne çıkmıştır. Üçüncü Dönem, 1995 ve 2010 yılları arasındadır. Bu dönemde internet ile televizyon yayıncıl1ğ 1 başlamıştır. 2010'ten sonra ve içinde yaşadığımız 2021'e kadar uzanan döneme ise "Televizyon 4.0" tanımı yapılmıştır. Bu dönemde, televizyon yayıncılığının hemen tüm üretim ve yayın aşamaları IP TV ve dijitalleşme yönünde değişiyor. Yayıncılık, yüksek teknolojiyle birlikte bölünüp farklı internet ortamlarına kaymaktadır (Jenner, 2014: 2).

Sanayideki üretim sıçramasıyla, televizyonun, internet üzerinden yayın yapan sayısal paydaşlarına aynı zamanda dağılmasına imkân verilmiştir. Bu nedenle de, televizyon yayın üretim anlayışı, dijital evrimden etkilenmiştir. İnternetin, televizyonla buluştuğu noktada, dördüncü bir televizyon evresi oluşmuştur. Televizyon 4.0 döneminde, "öde ve izle" özelliklerine sahip televizyon yayıncılığı, temel manada kurgusal bir iktisadi sistemin, dijitaldeki karşılığ1 olmuştur (Gezgin, 2018:586-588).
Televizyon 4.0 ile yayınların internet ortamıla paylaşılması, öde ve izleye dayalı sistemlerin gelişmesi, televizyonun yayınlanma mecralarının genişlemesi, teknik üretimde insan faktörünün azalması, ilk oluşan özelliklerdir (Johnson, 2007: 6).

\subsection{TRT Genel Müdürlüğü'nün Sanayi 4.0 Yönün- deki Yatırımları}

Dördüncü sanayi devrimi, üretimin organize edilmesi için dijital sistemlerin faaliyete geçirilmesini şart koşmaktadır. İnsan emeği, üretimin ana gücü olmaktan çıkmaktadır. Sanayi 4.0, sensörler yardımıyla üretim ortamının analiz edip ihtiyaçları fark edebilen yazılımlar ile üretimin daha kaliteli, güvenli, ucuz ve verimli olması hedeflenmektedir (Sünbül, 2018:23).

Sanayi 4.0 üretim sistemi olan Siber-Fiziksel Sistemler, karma bir teknoloji tarafından yönetilen sistemlerdir (Siskon, 2017:8). Yine otonom robotlar, bir operatör ile çalışabildikleri gibi, bir yazılım ile bağımsız üretim yapilabilmektedir.

Bu tanımlamalar ışığında; TRT, kavramsal olarak Sanayi 4.0 stratejisini aktif olarak kullanmamasına rağmen yakın bir gelecekte TRT'nin hizmet sektöründe Sanayi 4.0 uygulamasını iyi yansıtan bir kurum olabileceği yorumlanmaktadır. Çünkü TRT Kurumu'nun, bu makalenin ana konusu olan Sanayi 4.0'ın içeriğine yönelik önemli yatırımlar yaptığı tespit edilmiştir.

TRT Kurumu, 2008 yılında; farklı dillerde televizyon, radyo ve internet yayınıyla "küresel bir medya grubu olma stratejisini" hazırladı. TRT, farklı dillerdeki yayın markalarını kurduktan sonra 2015 yılından itibaren dijitalleşme yatırımlarını artırdı. 2020 yılından sonra da "akıllı yayın stratejilerine" geçen TRT, robot yazılımlar ve "insansız çalışma anlayışıyla" yeni yatırımlar yapmaya başladı. TRT'nin, yatırımlarını yoğunlaştırdığı dijital yayın teknolojileriyle, Siber Fiziksel Sistemi'nin ve Otonom Robot üretim sisteminin alt yapısını hazırladığı yorumlanabilmektedir.

TRT Kurumu'nda İlk etapta, muhabirlerin, prodüktörlerin, yapımcıların TRT kurumuna gelmeden yayını hazırlayabilmeleri; daha sonraki aşamalarda "insansız yayın alt yapılarının" oluşturulması hedeflenmektedir.

TRT'de, program sorumlusu prodüktörler ve yapımcılar; TEPÜYAP isimli yazılımı kullanarak yüz yüze iletişimi en alt seviyede kullanarak yayını hazırlayabiliyorlar. Program Sipariş Modülü, Program Öneri Modülü, Program Yapım Modülü ve Yayın Kontrol Modülü ve Muhasebe Modülüyle ile programlar hazırlanmaktadır. Yine yayın ve idari çalışanların son dönemde evlerinden çalışmaları, internet üzerinden zincirleme üretim yapmaları sağlandı (Röportaj A1). TRT'nin televizyon yayıncılığını yaparken kullandığ kamera sisteminin akıllı robotlarca yönetilmesi; teknik 
yayın kontrollerinin robot yazılımlar eliyle yapılması, mekânsız yayıncılığın yaygınlaştırılması, yayında ve idari işleyişte insan faktörünün azaltılması, TRT'nin sanayi 4.0 özelliklerini yansıtmaktadır.

Sanayi 4.0 üretim sistemine uyumlu yayın teknolojilerinin denenmesi, sayısal yayınların takip edilmesi ve kalite testlerin yapılabilmesi için; "Yayın İzleme ve Ölçüm Sistemleri" yazılım sistemi 7/24 yayın üretimi otomatik ve uzaktan izlenebiliyor (Röportaj, A2).

Sanayi 4.0'ın üretim süreçlerinden olan Bulut Bilişim Sistemi, çevrim içi bilgi dağıtımı; bilişim cihazları arasında ortak bilgi dağıtımını mümkün hale getirebilmektedir. TRT'de kullanılan bulut bilişim sistemi, farklı daire başkanlıklarının teknik yatırımlarında kullanılmaktadır. TRT'nin “yayın teknolojilerindeki tüm sistemlerin dijitalleştirilmesi" hedefiyle, fiziksel cihaz sunucuları sanal ortama aktarıldığı, TRT Genel Müdürlüğünde yapılan saha araştırmalarında ve röportajlarda tespit edilmiştir.

TRT kurumu, 2017 yılından itibaren uzaktan prodüksiyon, IP alt yapılı yapım ve yayın işleyişi $5 \mathrm{G}$ sistemiyle iletim için teknik yatırımlarını yapmaktadır. TRT, televizyon yayıncılığının son aşaması olan karasal sayısal yayın teknolojilerine geçip; dijital sistemle yayını sürdüren, yayın kontrolünü sağlayan ve hata durumlarını bildiren sistem için önemli yatırımlar yapmaktadır. 2021 Nisan ayı itibariyle karasal sayısal yayın teknolojileri için TRT Haber, TRT 1, TRT Spor, TRT Çocuk ve TRT Belgesel kanallarında deneme yayınları yapılmaktadır (Röportaj, A3).

Türkiye içinde ve ülke dışında, IP alt yapılı sistemler üzerinden yapılan yayın iletimlerinde 14 adet taşınabilir video iletim cihazı alan TRT, yayın yedeklemesini ve olağan üstü dönemlerde kiralık cihazlardan sinyal alma seçeneğiyle yazılım ve teknoloji yatırımı yaptı. Yine internet trafiğinin yoğunlaştığı zamanlarda yayının kesilmemesi için yeni nesil HEVC kodekli 2 adet transmitterı haber yayınlarına uyumlu hale getirilmiştir (Röportaj A2).

TRT, Ankara'da bulunan Genel Müdürlük binasında veri merkezi ağına yatırım yaparak anahtarlama sistemlerini modern hale getirdi. Böylece TRT'nin bölge temsilciliklerinin yayın sistemine hizmet veren omurga anahtarlama araçları yüksek ara yüz sayısı ve bant genişliğine sahip oldu. Aynı doğrultuda yayın akış birimleri için uyumlu modül yazılımları geliştirildi. Yayın devamlılık teknik sisteminin manuel çalışma sistemi; yapılan yeni yazılımlarla otomasyona bağlanmıştır. Frekans takip ve planlama sistemi yazılım ile insan faktörünün en alt şekline dönüştürüldü. Enerji Modülü ile çalışan teknikerlerin, bir ay boyunca çalışarak yaptıkları mutabakat işlemleri robot yazılım anlık takip edilebiliyor. Yayın aksamalarına neden olabilecek aksaklıklar robot yazılım ile otomatik ola- rak ortaya çıkacak ve gereken müdahale saniyelerle ile çözülecek hale getirilmiştir (Röportaj A2).

Sanayi 4.0 üretim şeklinin önemli bir özelliği olan "Sistem Entegrasyonu" birkaç sistemin tek bir mekanizmada birleştirilerek; tek bir sistem olarak çalışmalarını sağlamaktadır. TRT'nin yeni yayın teknolojilerindeki yatırımlarıyla önümüzdeki süreçte bu sistem uyumunun gerçekleşebileceği öngörülmektedir.

Haber Yayın Otomasyon Sistemlerinde ve Devamlılık Stüdyoları'nda bulunan yayın sistemlerinde bulunan yayınlar; sayısal arşiv yazılımı arasında sağlanan tam koordinasyon ile otomatik olarak arşivlenmektedir. Böylece TRT'nin 16 televizyon kanalındaki binlerce farklı yayın, insan faktörüyle tek tek arşivlenmeden; yazılımlar aracılığıyla otomatik arşiv sistemi oluşturulmuştur. Sayısal Arşiv Sistemi içindeki çok sayıdaki yazılım ve donanım bileşenleri ile ana ve yedek sistem odalarının işletilmesi ve zamansız takibi yapılabiliyor (Röportaj A1).

TRT bünyesinde oluşturulan “Teknik Araştırma ve Geliştirme Müdürlüğü" son 4 yılda; saat, uzaktan izleme-kontrol sistemleri, 1şık askı ve dimmer sistemlerin oto kontrol birimlerinde insan faktörünü azaltıcı işlemler yaptılar.

2012 yılında seslendirilen "kasetsiz yayıncılık" ileri safhaya getirilerek; video, ses, kamera, 1şık, sahne görüntü mekanizmalarını geliştirilen yazılımlar ile dijital tabanlı yayın sistemlerine dönüşmüş durumdadır.

Program yayın ve yapım işleri için; sistem sunucuları, kurgu setleri, Viz Engine, Viz Trio kurulumu yapılarak; setler arası iletişim bağlantılarıyla reji (yönetim) ve prompter kontrol ünitesi dijitalleştirilmiştir (Röportaj A1).

TRT Genel Müdürlüğü'nün tüm Türkiye'de 5300 metrekare alanda, 24 televizyon stüdyosu bulunmaktadır. TRT Kurumu, stüdyo çekimlerinde çok farklı görüntü alınabilmesi ve mekânsız çekimler için sanal stüdyo yatırımlarını son 10 yılda yoğunlaştırdı. TRT, yeni yatırımlarıyla eski nesil sanal stüdyolardan farklı olarak izleyiciye tam soyut bir mekân ve yaşanmışlık hissi veren gerçekçi izleme ortamı yansıtmayı hedefliyor. TRT stüdyolarında 2010 yılında başlayan kameramansız kamera çekimleri "robot kamera" sistemleriyle gerçekleştirilebiliyor. Hareket kabiliyeti yüksek kameralar, özel yazılımlar yardımıyla stüdyo çekimleri yapılabiliyor. TRT Stüdyolar ve Program İletim Sistemleri Dairesi Başkanlığı, küçük alanların stüdyoya dönüştürülmesini ve insan emeğinin alt düzeye indirilmesi için; kamera kayıt, ışık ve yayın verilerinin, dijital olarak transfer edilebilmesine fırsat veren uzaktan kontrol ve kumanda sağlayabilen yayın stüdyolarının dizayn edilmesi için çalışmalar yapmıştır (Röportaj, A2, A3). 
TRT 2 televizyon kanalında, yeni nesil "green screen" uygulaması sanal stüdyo uygulamalarının son örneğini yansitıyor. TRT 2'deki Sanal Stüdyo örneğinde; 10 yıl önce yaygınlaşan "greenbox" sisteminden daha modern olarak; program mekânlarını bir oyun motoru üzerinden oluşturuldu. Uygulama ile gerçek zamanlı yayınlanabilen yüksek kalitede stüdyo görüntüsü izlenebiliyor. Yazılım ile sağlanan bu stüdyo görüntüsünün, sanal stüdyolardan üstünlüğü izleyiciye doğal bir izlenim tecrübesi sunması olarak gösteriliyor. 2019'da 21 farklı sanal mekânda; 12 farklı program hazırlandı, 359 yayın çekilmiştir (Eren, 2019, 2020).

TRT World stüdyosu program bölümünde ise artırılmış gerçeklik ve sanal stüdyo uygulamaları için gerekli "Tracking" sistemi" hazırlandı. Ayrıca TRT World stüdyosunun; telsiz, masa altı ayak kontrol, masa üstü sistemleri ve prompter kontrol donanımları dijital sistemle "akıllı hale" getirilmiştir (Eren, 2017, 2018).

Mekânsız yayınlar için birçok program sunucusunun evine küçük stüdyo yapıları hazırlandı ve programlar evden sunulmasına rağmen; stüdyo ortamı ekrana yansıtıldı. Ayrıca "artırılmış gerçeklik" yöntemiyle gerçek çevre görüntüsünün, yazılım ile üretilen görüntü, ses, grafik ve GPS verileriyle zenginleştirilmesiyle elde ediliyor. Ayrıca dış çekim ve küçük stüdyolar için 1şık-spot uyumunu gerçekleştiren "1şık masası yazılımı" oluşturulmuştur. Yazılım sektöründen önümüzdeki dönemde yeni satın almalarla bu yönde yayın yatırımı yapılacaktır (Röportaj A1).

Sadece yayın sisteminin değil; idari yapılanmanı da yazılımlar üzerinden dijital hale gelmesini isteyen TRT yönetimi, son yıllarda idari yazışmalar için; otomasyon, takip, kontrol ve yönetim sistemleri için yazılımlar satın aldı. Reklam Yönetim Sistemi yazılımını kullanarak, program yapımcılarıyla, reklam servisi arasında yüz yüze iletişim zorunluluğunu kaldırdı. Güvenlik ve teknik serviste personel nöbetlerini oluşturmak için nöbet otomasyon sistem yazılımı satın alındı. Kurum, son 4 yıldır, TUBITTAK yardımıla otomatik dijital imza uygulamasını kullanmaktadır (Eren, 2016-2020).

Televizyon sektöründe dijitalleştirme yatırımlarıyla kültürel miraslar korunup, dünyanın her yerinden internet erişimi ile çevrimiçi olarak görüntülenebiliyor (Constantinidis, 2016:225). Kültürel yayın mirasın korunup gelecek kuşaklara aktarımı dijital ortama aktarılarak Sanayi 4.0 üretim enstrümanlarıyla korunması projelerine dünyada "Etiket Bulutu projesi", "Cooltura Platformu" ve "Europeana" örnek gösterilebilmektedir.

TRT Kurumu, Sanayi 4.0'1n altı yapısını kurarak sadece teknolojik kolaylıklar elde etmiyor. Yeni nesil teknoloji ile kültür mirası yayınların arşivi ve yayılması ucuz ve kolay olabilmektedir. Haber Medya Yönetim Sistemi ve Sayısal Arşiv sistemi sayesinde 2019 yılında sisteme 237 bin yayın kaydı yapılabildi. TRT internet üzerinden, 57 yıllık yayın tarihinin önemli kültür yayınlarını ücretsiz olarak paylaşıyor (Röportaj A3).

24 yaş altındaki izleyiciyi kazanmak ve yeni yayın teknolojilerine uyum sağlamak isteyen TRT, 16 televizyon kanalına alternatif olarak iki büyük dijital yayın platformu kurmak için çalışmalar yapıyor. Türkiye'de internet kullanıcısı olma oranı yüzde 83'e yükseldi. İnternette en çok zaman, çevrim içi televizyon izlemeyle ve sosyal medya ile geçiriliyor. Bu nedenle TRT'nin dijital televizyon markası oluşturması gelecekte markasını koruması için mutlaka gerekli bir yatırım olarak yorumlanıyor. Dijital yayın platformlarının öncelikli hedef kitlesi 14-24 yaş aralığı olacak. İki dijital medya platformları için çalışmalarını sürdüren TRT yönetimi, benzer yayın platformlarının dünyadaki toplam abone sayısı 1 milyarı geçmesi ve Netflix isimli yayın markasının 200 milyon aboneyi aşmasını örnek almaktadır (T24:TRT İki Yeni Dijital Platform Kuruyor ).

Yayıncılık sektöründe Sanayi 4.0 kapsamında; yapay zekâ geliştirme uygulamaları başlamıştır. Bu uygulamalarda normal bir robotta kullanılan yapay zekâdan farklı olarak, sanal ortamdan haber değeri olan yeni ve doğru veriyi filtreleyip yapay zekâ tarafından komutsuz olarak yayına alınabiliyor. Yapay zekâ ile haber yapmak için Google'ın sponsor olduğu "The Digital News Initiative" isimli bir proje bulunuyor. Bu proje, yayıncılık dünyası için tasarlanmış olan yapay zekânın, büyük veri üzerinden bilgileri toplaması ve yerel medya işletmeleri için ayda 30 bin haber yapması hedefleniyor. Yayıncılık sektörüne özel yapay zekânın oluşturulması; medyanın Sanayi 4.0'a uyumu sürecinde yapılması gereken en önemli işlerden biri kabul edilmektedir (Akgül ve Ayer, 2018:2321).

Yapay zekânın yayıncılıkta aktif olarak kullanılabilmesi, Sanayi 4.0'ın “kişiye özel üretim kriterinin” yerine getirilerek; kişiye, kitleye yönelik özel haberlerin, yayınların oluşturulabilmesi sağlayacaktır. Televizyonculuk sektöründeki kullanılacak yapay zekâ, normal bir robotta kullanılan yapay zekâdan farklı olarak, internet üzerinden haber olabilecek güncel ve doğru bilgiyi belirli kıstaslarla değerlendirip; bunu haber yapabilecek ve gelen tepkilere ve okuma özelliklerine göre de; aynı yönde ya da zıt yönde haber yapımını zamansız, insansız ve mekânsız sürdürecektir.

TRT kurumunun ise henüz, yapay zekâ ile muhabiri devre dışı bırakan haber üretimi ve program yapımc1sını devre dışı bırakan "senaryo, program metin üretim yazılımı" bulunmamaktadır (Röportaj A1,A2,A3). TRT Kurumu, sosyal medya şirketlerinin yaptığı, "hedef kitlenin beğeni yönelimine göre yayın hazırlama, reklam oluşturma algoritmalarına" dair bugüne kadar bir yazılım yatırımı yapmamıştır (Röportaj A1,A2,A3). 
Yayıncılık sektöründe; internet ve dijitalleşme ile birleştiğinde "büyük veri" ismiyle oldukça geniş bir bilgi ağı ortaya çıkmış ve doğru bilgi öne çıkıştır. Büyük veri; “onlarca türü olan dijital yayın mecralarında bulunan bilginin anlamlı ve işlenebilir biçime dönüştürülmüş biçimi" olarak tanımlanmaktadır. Bilginin önem kazanmasıyla da, iletişim ve haber yorumları da değişmiştir. Bu değişimle birlikte yayının/haberin yorumlanması süreçleri de farklılaşmıştır. Yayının hazırlanması ve yayına gelen tepki biçimleri Sanayi 4,0 uyum çalışmalarıyla değişime uğrayacaktır (Akgül ve Ayer, 2018: 2312) Çünkü gelişmiş yazılımlar; haberin/ yayının hangi saatlerde okunduğunu, hangi yaş aralığında kimlere hitap ettiğini, nasıl ilgi gördüğünü vb. sonuçları analiz edebiliyor.

Dijital yayıncılığın ve Sanayi $4.0^{\prime}$ ın yaygınlaştırdığ yeni yayın üretim anlayışıyla; yazılımlar, haber ve program verisini düzenlenip hedef kitle için anlamlı hale getirebiliyor. Veri gazeteciliğinin raporlama tekniği ile okuyucu/izleyici süreç yayın içerisine çekilebiliyor. Hedef kitlenin isteklerine yönelik yayın hazırlanabilmektedir.

Sanayi 4.0 ile gelişmiş sensör teknolojileri ve bu sensörlerden gelen verileri analiz eden makinaları ve yazılım robotlarını kullanabilen yüksek vasıflı insan kaynağı oluşacaktır. Bu durum, endişe edildiği gibi işsizlik büyümesine sebep olmayacağ ${ }_{1}$ hatta istihdam artışını sağlayacağı öngörülüyor (Koca, 2018: 245-250) Ancak Scheer firmasına göre, Sanayi 4.0 sürecinde en büyük zorluk insan kaynağında olacak (TOBB, 2016:22). Çünkü Sanayi 4.0 çalışma şekliyle gelecekte; robotik sistemler, yapay zeka, otomasyon, ileri mühendislik ağları, nesnelerin interneti sensörler, veri toplama sistemleri ve simülasyon gibi birçok yeni ve farklı disiplini barındıran sayısallaştırılmış üretim biçimleri oluşacaktır (Tamás ve Illés, 2016).

Sanayi 4.0 yeni üretim tarzında çalışacak personel için TRT'nin mevcut personelinin yeterli olmayacağı yorumlanmaktadır. TRT yeni nesil çalışmalarda mevcut personelinden yeteri kadar verim alamayınca, “Özel Hukuk Hükümlerine Tabi Personel" yönetmeliği hazırladı ve bu sayede yeni çalışan alabiliyor. Bilgi İşlem Dairesi Başkanlığı'na sınırlı sayıda yeni yazılımlara ve teknik yatırımlarla uyum sağlayabilecek çalışan alınmiştır (Röportaj A2).

\subsubsection{Covid 19 Döneminde TRT'nin Sanayi 4.0 Yat1- rımlarının Artması}

Sanayi 4.0'ın ana üretim mantığı, dijital yatırımların artırılarak, insan faktörünün azaltılması ve başlayan otomasyon sistemi olarak özetlenebiliyor (Rzayeva, 2018:45-55). TRT Kurumu, Covid 19'un salgınının olağanüstü şartlarında insan faktörünü azaltıp; mekânsız, zamansız ve insansız yayın üretimini hedeflemiştir.
Covid 19 salgın sürecinde, TRT kurumu; yayıncılığ1 dijitalleşme yönünde artırarak ve mümkün olan en az insan emeğini kullanarak, dördüncü sanayi devriminin alt yapı çalışmalarının yapıldığı (ampirik) bir çalışma alanına dönüşmüştür.

Toplu çalışma hayatında kolayca yayılabilen Covid-19 virüsü sebebiyle; yayın üretimin zorlaştı̆ğ ve işgücüne erişimin kısıtlandığ 1 kriz döneminde, teknoloji tabanlı üretim mekanizmaları TRT için büyük önemli hale gelmiştir. Bu süreç 25 Mart 2020'de başlayıp halen (04.05.2021) devam etmektedir.

TRT Kurumu, Covid 19 virüsünün kurum çalışanları içinde yayılmasını engellemek için insan girdisinden bağımsız yayın üretimini başarmak istemiştir.

TRT Genel Müdürlüğü 25 Mart 2020'de aldığı idari kararla; en az sayıdaki personelin işe gelmesini ve hemen tüm işlerin uzaktan çalışma ile yapmasını istemiştir. Stüdyo haber çekimleri, habere ulaşmak, teknik yayın hazırlıklarının bir kısmı, TRT genel merkezinde gerçekleşirken; çalışma sisteminin yaklaşık olarak üçte ikisi, insansız ya da mekânsız olarak gerçekleştirilmeye başlamıştır.

TRT Kurumu'nda 6 bin 800 kişi çalışmaktadır. Bu makaleye konu olan saha araştırmasındaki TRT Genel Müdürlük binasında ise 4 bin 50 kişi çalışmaktadır. TRT Kurumu yaklaşık 14 aydır 4 bin 50 çalışanının sadece 450'sini aktif olarak kuruma çağırıp; bu kişileri de nöbet sistemiyle çalıştırmaktadır (Röportaj A1, A2).

Özellikle emek yoğun üretimin gerçekleştirildiği haber merkezi ve idari işler çalışmalarında yazılımlarla devreye alınmıştır. Kurumun yayın dışında çalışan personeli, TUBİTAK yardımıyla oluşturulan yazılım ile idari evrakları evlerinden hazırlayıp; dijital ortamda onaya sunmaktadırlar (Röportaj A3).

TRT'nin yayın personelinden haber muhabirleri, ışıkçı, yönetmen ve teknik ekip dışında diğer çalışanlar uzaktan yayın üretimi yapıyorlar, Örneğin habere giden bir muhabir yazdı ̆̆ı metni; evinden çalışan editöre yazılım sayesinde gönderiliyor; editör habere yaptığı düzeltmeleri haber koordinatörüne ve yönetmene göndermektedir. Bu işleyiş 14 aydır devam etmektedir (Röportaj A3).

TRT Genel Müdürlüğü'nde çalışan 410 prodüktör uzaktan çalışma yöntemiyle; program tekliflerini, montaj, kurgu ve senaryo aşamalarını yüz yüze iletişime geçmeden gerçekleştirebilmektedirler.

Program Master, Sözleşme Yönetim Sistemi, Program Master Modülü, Yayın akışı, Raporlama Sistemi, Telif Sistemi ve program üretim sistemi özel bir yazılım ile e-televizyon otomasyon sistemine dönüştü. Prodüktörler ve program yapımcıları, idari ve teknik kadroyla yüz yüze gelmeden program teklifi, işleyişi ve 
yayınını hazırlayabiliyorlar (Röportaj A2).

TRT kurumunda bulunan 25 daire başkanlığının birer çalışanı nöbet sistemiyle kurum mesaisine gelip; zorunlu evrakları dijitalleştirip idari onaylara göndermektedirler. TRT kurumunun aktif daire başkanlıklarında olan Eğitim Dairesi 14 aylık süre içinde çevrim içi eğitimler düzenleyerek; kurum için eğitim programlarını aksatmamıştır. Aylık olarak ortalama 7 eğitim programı düzenleyen Eğitim Dairesi Başkanlığı'nın dijital eğitimlerine katılım ise yüz yüze eğitim sayılarıyla eşit olmuştur (Röportaj A3)

Covid 19 salgın döneminde TRT Genel Müdürlüğü'nde yeni yazılımlar oluşturulmuş; bulut bilişim büyütülmüş ve eklemeli üretim oluşturulmak istenmiştir.

TRT, 2010'da ilk kez denediği robot kamera sistemini, Covid 19 döneminde tüm stüdyolarında uygulayarak; "kameramansız kamera çekimlerini" başarılyla gerçekleştirmiştir (Röportaj A1).

Covid 19 salgın günlerinde, TRT Kurumu, uzaktan eğitim için TRT EBA İlkokul, TRT EBA Ortaokul ve TRT EBA Lise'yi, az sayıda çalışan ile sanayi 4.0 üretim tekniklerine uyum sağlayabilecek sistemlerle yayına hazırladı. TRT, sanal eğitim filmlerini hazırlarken; kendisi de mümkün olan en alt limitte mekân ve insan faktörünü kullanmış ve yüz yüze iletişimi az seviyeye indirmiştir. 16,5 milyon ilk ve orta öğretim öğrencisi, EBA eğitim setinde artırılmış gerçeklik uygulamaları, görselleştirme uygulamaları çevrim içi eğitim sınıfları ile ihtiyaç duydukları eğitimleri alabilmiş ve eğitmenleriyle iletişim kurulabilmişlerdir (Röportaj, A1, A2, $\mathrm{A} 3)$.

\section{SONUÇ VE ÖNERILLER}

Saha araştırma sonuçlarının ve röportaj bilgilerinin yardımıyla, TRT kurumunun Sanayi 4.0 üretim tekniklerine tamamen geçmediği tespit edilmiştir. Ancak yakın bir gelecekte TRT'nin medya sektöründe Sanayi 4.0 uygulamasını iyi yansıtan bir kurum olabileceği yorumlanabilmektedir. TRT Genel Müdürlüğü'nün özerk yönetim yapısı, teknik yatırımlara ayrılabilecek mali bütçesinin olması, yayıncılık sektörünün yeniliklere açık olması önemli avantajlar olarak yorumlanmaktadır.

TRT Kurumu, "küresel bir yayın olma hedefi" ve "yayın araçlarının tam ve yayın üretim tekniklerinin dijitalleşmesi" stratejisiyle kavramsal olarak, Sanayi 4.0 üretim şeklinin alt yapısını oluşturmaktadır.

TRT Genel Müdürlüğü'nün Sanayi 4.0 üretimi sürecine yönelik yatırımlar yapmasıyla; dijital yayıncılık ve akıllı robot yazılımları ile habere ulaşmak ve yayını tüm dünyayı ulaştırmak çok daha ucuz hale gelmektedir. Sanayi 4.0 akıllı yayın teknolojileri izleyici/dinleyici hedef kitlenin kültürel içeriğin yorumlanmasına, yönlendirilmesine, değerlendirilmesine ve ortak olmasına yardımcı olabilecektir. Kültürel yayın miraslarının sayısallaştırılması ve farklı yayın ortamlarıyla geniş kitlelerle paylaşılması; yine Sanayi 4.0 üretim şekilleriyle daha aktif hale gelebilecektir.

2021 yılında, TRT'nin dijital yayın yatırımları, robot yazılım teknolojilerinin kullanılmasıyla insansız, zamansız ve mekânsız yayın anlayışı için yaptığı yatırımlar devam etmektedir.

Bu anlamda TRT'nin önümüzdeki süreçte önce Sanayi 4.0'ın karşıllı̆ 1 olan “Televizyon 4.0” yönünde strateji geliştirip; yatırımlarını daha bilinçli şekilde planlamas1 tavsiye edilmektedir.

TRT Kurumu'nun, Sanayi 4.0 bağlamında yeniden yapılanmasına yönelik olarak yapması gereken temel değişiklikler olarak; televizyon yayın sektörüne özel üretilmiş yapay zekâ tasarlanması ve sanayi 4.0 üretim sistemiyle uyumlu çalişabilecek personel ve yönetici yetiştirmesi, önerilmektedir.

TRT Genel Müdürlüğ̈̈'nün teknik yatırımlarını farklı daire başkanlıkları gerçekleştirdiği için bütüncül bir çalışma yapmak zorlaşmıştır. Makale çalışmasının pandemi döneminde yapılması nedeniyle teknik ekip sorumlularına ulaşmakta zorluk yaşanmıştır. TRT yönetiminin, çalışanlarına yönelik kısıtlayıcı konuşma yasakları ve teknik yatırım maliyetlerinin açıklanmaması makale çalışmasının kısıtlı alanlarını oluşturmaktadır.

\section{KAYNAKÇA}

ABERSFELDER, S., BOGNER., E., HEYDER A. \& FRANKEL, J. (2016). Application and Validation of an Existing Industry 4.0 Guideline for the Development of Specific Recommendations for Implementation, Advanced Materials Research, 1140, 465-472.

AKGÜL, B. \& AYER, Z. (2018). Sanayi 4.0 Sürecinde Medyada Sektörel Dönüşüm, OPUS-Uluslararası Toplum Araştırmaları Dergisi, 9(16), 2310- 2327.

ALMADA, L.F. (2015). The Industry 4.0 Revolution and the Future of Manufacturing Execution Systems (MES), Journal of Innovation Management, 3(4), 16-21.

ALBERS, A., GLADYSZ, B. \& PINNER, T. (2016). Procedure for Defining the System of Objectives in the Initial Phase of an Industry 4.0 Project Focusing on Intelligent Quality Control Systems, Procedia 52, 262-267.

BAĞCI, E., (2018). Endüstri 4.0: Yeni Üretim Tarzını Anlamak, Gümüşhane Üniversitesi Sosyal Bilimler Enstitüsü, 9/24 122-123.

BAYRAM Y.(2013). Küreselleşme Sürecinde Medya Sektörünün Değişen Doğası ve Türk Medya Sektörüne Yansımaları, Emek ve Toplum, 2/2: 3,1. 
BRANKE, J., FARID, S. \& SHAH, N. (2016). Industry 4.0 - A Vision also for personalized medicine supply chains?, Cell and Gene Therapy Insights, 2(2), 263-270.

CONSTANTINIDIS, D. (2016). Crowdsourcing Culture: Challenges to Changell, Borowiecki vd. (Yay. haz.), Cultural Heritage in a Changing World içinde, 215-236 Switzerland: Springer International Publishing AG.

EFFRA (2013). Factories Of The Future, MultiAnnual Roadmap For The Contractual PPP Under Horizon, https://ec.europa.eu/ research/industrial_technologies/pdf/ppp-factories-of-the-future-strategicmultiannual-roadmap-info-day en.pdf (Erişim Tarihi: 28.04.2021)

EMARA, N. \& KASA, H. (2020. The non-Linear Relationship Between Financial Access and Domestic Savings: the Case of Emerging Markets, Applied Economics, 53(20):1-19.

EREN, İ. (2020). TRT Faaliyet Raporu, Ankara: TRT Yayınları.

EREN, İ. (2019). TRT Faaliyet Raporu, Ankara: TRT Yayınları

EREN İ. (2018). TRT Faaliyet Raporu, Ankara: TRT Yayınları

GÜVENÇ. D., YÜCEBALKAN, B., DEMIRCILİ, E. \& AKSU, B., , Geleceğin Akıllı işletmeleri Projeksiyonunda Yeni İşgücü Olarak Z Kuşağının Teknolojiye Yönelik Tutumları, I. Uluslararası Bilimsel ve Mesleki Çalıșmalar Sempozyumu (Bilmes, 17 Haziran, 2017) Tam Metin Bildiri Kitabı, 1-9, 58-65.

GEZGiN, S. (2018). Televizyon 4.0, TRT Akademi Dergisi, 03/06, 580-589.

IEC, (2015), Factory of The Future, White paper. http://www.iec. ch/whitepaper/pdf/iecWP-futurefactory-LRen.pdf (Erişim Tarihi: 21.05.2021).

IVANOV, D., DOLGUI, A. \& SOKOLOV, B. (2016). A Dynamic Model and an Algorithm for Short-Term Supply Chain Scheduling in the Smart Factory Industry 4.0., International Journal of Production Research, 54(2), 386-402.

JENNER, M. (2014). Is this TVIV? On Netflix, TVIII and binge-watching, New Media \& Society, 1-17 https://journals.sagepub.com/doi/abs/10.1177/1461444814541523 (erişim tarihi: 19.05.2021)

JOHNSON, C. (2007). “Tele-Branding In TVIII." New Review of Film and Television Studies, 5 (1), 5-24.

KASA, H. \& ARSLAN G. (2020). Endüstri 4.0 Kapsamında Teorik Bir Analiz: Türkiye Örneği, Elektronik Sosyal Bilimler Dergisi, 19/ 76, 1810-1826.

KIVILCIM, B. (2020). Covid-19 Salgınının Turizm Sektörüne Muhtemel Etkileri, Uluslararası Batı Karadeniz Sosyal ve Beşeri Bilimler Dergisi, 4(1), 17-27.

KOCA, K., C., (2018). Sanayi 4.0: Türkiye Açısından Fırsatlar ve Tehditler", Sosyo ekonomi Dergisi, 26(36), 245-252.

KOÇAK, R. (2020). Beşinci Sanayi Devrimi: Toplum 5.0 ve Yapay Zekâ Kültürü, Uluslararası Halkbilimi Araştırmaları Dergisi, 5, 1-17.

ÖZTÜRK, S. \&ALAŞAHAN, Y. (2019). “Türkiye'de Endüstri 4.0 Uygulamalarının Değerlendirilmesi: Panel Veri Analizi” Dumlupınar Üniversitesi Sosyal Bilimler Dergisi, 61,1-18.
ÖZDOĞAN, O. (2017). Endüstri 4.0, İstanbul: Pusula Yayınları.

ÖZATA, F. (2016). Türkiye, Endüstri 4.0 ile dünya devi olacak, https://www.yenisafak.com/teknoloji/turkiye-endustri-40-ile-dunya-devi-olacak-2568622 (Erişim Tarihi: 20.05.2021).

RZAYEVA, S. (2018), Küreselleşme Kapsamında İletişim Teknolojileri ve Somut Olmayan Kültürel Miras İlişkisi, Akademik Sosyal Araştırmalar DOI: 10.31455/asya.416771/ Sayı: 5, s. 45-55.

SURİ, K., A., CUCCURU A., CADAVID, S. \& TATA, S. (2017), Model-Based development of modular complex systems for accomplishing system integration for Industry 4.0, 5 th International Conference on Model-Driven Engineering and Software Development (MODELSWARD 2017), Feb. 2017, Porto, Portugal.

SCHWAB, K. (2016). Dördüncü Sanayi Devrimi, (Çeviren Dicleli Z.), İstanbul: Optimist Yayınevi.

SÜNBÜL, G. (2018). "Endüstri 4.0 Nedir?, Ne Değildir?, Kullanım Alanları Nerelerdir?." https://www.dia.com.tr/endustri-4-0-nedir-ne-degildir-kullanim-alanlari-nerelerdir/ $05.05 .2021)$

ŞUMAN, N. (2017). Akıllı Üretim Çağl: Endüstri 4.0, 30 Nisan 2021 tarihinde, Akı1lı üretim çağı: Endüstri 4.0 |_Fortune Turkey https://www.fortuneturkey.com/akilli-uretim-cagi-endustri-40-42841adresinden alınmıştır.

TAMÁS, P. \& ILLÉS, B. (2016). "Process improvement trends for manufacturing systems in industry 4.0." Academic Journal of Manufacturing Engineering, 14, 4.

TÜRK, A., KARTOĞLU, C., KIRCI, B., TOS, K., ÇABUK, G., PIRNAL, S.C. \&KURUM, E. (2014). “Akıllı Yeni Dünya: Dördüncü Sanayi Devrimi”, https://issuu.com/avrupaisletmeleragi/docs/ endustri_4.0_ekoiq_kitapcik_een/6 (Erişim Tarihi: 06.05.2021)

TÜBİTAK, (2016). Yeni Sanayi Devrimi Akillı Üretim Sistemleri Teknoloji Yol Haritasl, https://www.tubitak.gov.tr/tr/haber/yeni-sanayi-devrimi-akilli-uretim-sistemleri-teknoloji-yol-haritasi (Erișim Tarihi: 01.04.2021).

TOBB. (2016). Akill Fabrikalar Geliyor, http://haber.tobb. org.tr/ekonomikforum/2016/259/016_027.pdf (Erişim Tarihi: 25.04.2021)

TRT İki Yeni Dijital Platform Kuruyor, https://t24.com.tr/foto-haber/trt-den-2-yeni-dijital-platform,11519/2 (Erișim Tarihi: 03.04.2021)

TRT Genel Müdürlüğü, (2015-2019). TRT Mali Bilanço Kitabl, Ankara: TRT Yayınları.

ÜNAL, O. (2018). Gemi İnşa Sektörünün Türk Deniz Ticaretinin Etkinlik ve Verimliliğinin Arttırlmasına Etkisi, Doktora Tezi, Türk Hava Kurumu Üniversitesi Sosyal Bilimler Enstitüsü.Ankara.

YÍĞITOL, B. \& SARI, T. (2020). Küresel Salgınlar ile Mücadelede Endüstri 4.0 Teknolojilerinin Rolü, Pamukkale Üniversitesi Sosyal Bilimler Enstitüsü Dergisi, 41, 53-73.

YÜZAK, Ö. (2016). Endüstri 4.0 tarihinde https://www.cumhuriyet.com.tr/yazarlar/ozlem-yuzak/endustri-40-dunya-turkiye-632227 (Erişim Tarihi: 03.04.2021). 